\title{
MENGEMBANGKAN KEMAMPUAN MANAJEMEN WAKTU MELALUI LAYANAN PENGUASAAN KONTEN DENGAN TEKNIK KONTRAK PERILAKU PADA SISWA KELAS VIII-2 SMP N 5 TEBING TINGGI
}

\author{
S. Rosnetty Saragih \\ Surel: srosnettysaragih01@gmail.com
}

\begin{abstract}
ABSTRAK
Penelitian ini bertujuan untuk mengetahui upaya dan keberhasilan dalam mengembangkan kemampuan manajemen waktu siswa melalui layanan penguasaan konten dengan teknik kontrak perilaku. Populasi penelitian yaitu kelas VIII SMP N 5 Tebing Tinggi yang berjumlah 224 siswa dan sampel yang berjumlah 28 siswa menggunakan purposeive sampling. Teknik pengumpulan data menggunakan kuesioner kemampuan manajemen waktu. Instrumen tersebut telah diujicobakan untuk digunakan dalam penelitian menggunakan validitas dengan rumus product moment oleh Pearson dan reabilitas instrument dengan rumus Alpha.Teknik analisis data yang digunakan yakni analisis deskriptif persentase dan Uji t (t-test). Hasil uji t, menunjukkan bahwa nilai thitung $=20,64$ dan tabel $=2,052$, jadi nilai thitung > ttabel. Dengan demikian, simpulan dari penelitian ini yaitu kemampuan manajemen waktu siswa dapat dikembangkan melalui layanan penguasan konten dengan teknik kontrak perilaku.
\end{abstract}

Kata kunci: Manajemen Waktu, Layanan Penguasaan Konten.

\section{PENDAHULUAN} aktivitas dari mulai pagi hari hingga malam hari. Aktivitas yang dilakukan juga berbeda-beda sesuai dengan kebutuhan dan kepentingan setiap individu, sebagai contoh seorang pelajar SMP dengan pelajar SMA meskipun mereka sama-sama mempunyai porsi kegiatan yang lebih banyak untuk belajar akan tetapi aktivitas yang mereka lakukan belum tentu sama semua. Waktu hendaknya dikelola dengan baik, jadi setiap individu diharapkan tahu kapan dapat menghabiskan waktu dengan sia-sia serta mengetahui kapan harus produktif. Waktu adalah sumber daya yang sangat berharga. Setiap orang di dunia ini memperoleh jumlah waktu yang sama, namun banyak diantara orang-orang tersebut yang merasa masih saja kekurangan waktu, tidak ada waktu, tidak mempunyai cukup waktu. Menurut Maman (Kurniadin dkk, 2012 : 23) kata manajemen yang umum digunakan saat ini berasal dari kata kerja to manage yang berarti mengurus, mengatur, mengemudikan, mengendalikan, menangani, mengelola, menyelenggarakan, menjalankan, melaksanakan, dan memimpin. Kata management berasal dari bahasa Latin, yaitu mano yang berarti tangan, menjadi manus berarti 

bekerja berali-kali dengan menggunakan tangan, ditambah imbuhan agree yang berarti melakukan sesuatu, kemudian menjadi managiare yang berarti melakukan sesuatu berkali-kali dengan menggunakan tangan-tangan. Sedangkan waktu terdiri dari siang dan malam yang tersusun dari satuan waktu terkecil detik, menit, dan jam, minggu, bulan, tahun dan seterusnya. Jadi dapat digabungkan bahwa manajemen waktu adalah usaha untuk memanfaatkan setiap bagian dari waktu untuk melakukan aktivitas tertentu yang mana telah ditentukan target dalam jangka waktu tertentu. Menurut Taylor (1990:9) manajemen waktu adalah pencapaian dari sasaran-sasaran utama kehidupan sebagai hasil dari menyisihkan kegiatan-kegiatan tidak berarti yang sering kali justru memakan waktu. Manajemen waktu adalah sasaran yang dapat kita mewujudkan khususnya bagi mereka yang memiliki motivasi. Dengan kata lain, manajemen waktu menuntut agar mampu mengalokasikan waktu dan sumber daya (yang terbatas) untuk mencapai tujuan yang dikehendaki. Manajemen waktu harus dilakukan dengan tepat karena hal ini berkaitan dengan waktu yang sifatnya tidak dapat berubah dan tidak ada penggantinya. Untuk menghabiskan waktu itu harus merencanakannya dengan baik. Misalnya dengan membuat jadwal harian, jadwal mingguan, jadwal bulanan dan jadwal tahunan. Selain itu juga dapat menentukan target dan mimpi dalam jangka pendek dan jangka panjang.

Menurut Prayitno (2004:2) Layanan penguasaan konten (PKO) merupakan layanan bantuan kepada individu (sendiri-sendiri ataupun dalam kelompok) untuk menguasai kemampuan atau kompetensi tertentu melalui kegiatan belajar. Kemampuan atau kompetensi yang dipelajari itu merupakan satu unit konten yang di dalamnya terkandung fakta dan data, konsep, proses, hukum dan aturan, nilai, persepsi, afeksi, sikap dan tindakan yang terkait di dalamnya. Layanan penguasaan konten ini perlu untuk menambah wawasan dan pemahaman, mengarahkan penilaian dan sikap, menuguasai cara-cara atau kebiasaan tertentu, untuk memenuhi kebutuhannya dan mengatasi masalahmasalahnya. Dengan penguasaan konten yang dimaksud itu individu yang bersangkutan lebih mampu menjalani kehidupannya secara efektif (effective daily living). Pemberian layanan dapat dilaksanakan dalam bentuk klasikal, kelompok dengan metode ceramah, diskusi dan dapat didukung dengan peragaan, pemberian contoh. Salah satu teknik pengembangan kemampuan manajemen waktu yaitu dengan teknik kontrak perilaku, yaitu membantu klien untuk membentuk perilaku tertentu yang diinginkan dan memperoleh ganjaran tertentu sesuai dengan kontrak yang disepakati 
(Latipun, 2006:144). Sedangkan menurut Gantina dkk (2011:172) Pembuatan kontrak adalah mengatur kondisi konseli sehingga konseli menampilkan tingkah laku yang diinginkan berdasarkan kontrak antara konseli dan konselor. Dengan teknik kontrak perilaku, siswa diajak untuk belajar dengan komitmen yang mereka buat sendiri berkaitan dengan manajemen waktu. Hal ini ditegaskan pula oleh Reza (2010: 105), bahwa jika bersungguh-sungguh akan mengelola waktu dengan benar, mulailah membuat suatu komitmen. Komitmen adalah perpaduan antara persistensi dan konsistensi. Kontrak perilaku diberlakukan sebagai suatu penguatan yang mengikat agar siswa belajar untuk menghargai dan menepati kontrak yang telah mereka buat sendiri terkait dengan pengaturan dan pengelolaan waktu untuk menjalani kegiatan mereka sehari-hari.

Penelitian ini bertujuan untuk memperoleh informasi atau temuan empiris tentang mengembangkan kemampuan manajemen waktu melalui layanan penguasaan konten dengan teknik kontrak perilaku pada siswa kelas VIII-2 SMP N 5 Tebing Tinggi, untuk mengetahui kemampuan manajemen waktu sebelum diberi layanan penguasaan konten dengan teknik kontrak perilaku, untuk mengetahui kemampuan manajemen waktu sesudah diberi layanan penguasaan konten dengan teknik kontrak perilaku, untuk mengetahui perbedaan kemampuan manajemen waktu sesudah diberi layanan penguasaan konten dengan teknik kontrak perilaku.

Menurut Sugiyono (2008:64) "Hipotesis merupakan jawaban sementara terhadap rumusan masalah penelitian, dimana rumusan masalah penelitian telah dinyatakan dalam bentuk kalimat pertanyaan." Dengan jawaban sementara ini membantu peneliti agar proses penelitinnya lebih terarah. Dalam penelitian ini ada dua variabel yaitu terikat manajemen waktu dan variabel bebas layanan penguasaan konten. Peneliti memberikan perlakuan layanan penguasaan konten dengan teknik kontrak perilaku untuk mengembangkan kemampuan manajemen waktu siswa. Berdasarkan teori yang dipaparkan di atas, maka hipotesis penelitian yang diajukan adalah layanan penguasaan konten dengan teknik kontrak perilaku dapat mengembangkan kemampuan manajemen waktu pada siswa kelas VIII-2 SMP N 5 Tebing Tinggi.

\section{METODE PENELITIAN}

Penelitian merupakan suatu proses artinya merupakan rangkaian langkah-langkah yang dilakukan secara terencana dan sistematis guna mendapatkan pemecahan masalah yang sesuai dengan tujuan penelitian. Metode penelitian adalah cara yang digunakan untuk menandai seseorang peneliti tentang urut-urutan bagaimana 
SEJ VOLUME 7 NO. 3 DESEMBER 2017

penelitian dilakukan. Dalam metode penelitian ini, terdapat beberapa hal yang dapat menentukan langkahlangkah pelaksanaan kegiatan penelitian. Hal ini bertujuan untuk melaksanakan kegiatan secara sistematis. Adapun langkah-langkah yang harus ditentukan adalah jenis dan desain penelitian, variabel penelitian, populasi dan sampel penelitian, definisi operasional, validitas dan reabilitas instrument, teknik pengumpulan data, dan teknik analisis data.

Jenis penelitian pada judul Mengembangkan Kemampuan Manajemen Waktu Melalui Layanan Penguasaan Konten dengan Teknik Kontrak Perilaku Pada Siwa Kelas VIII-2 SMP N 5 Tebing Tinggi adalah penelitian eksperimen atau percobaan (eksperimental research). Penelitian ini Dilaksanakan Pada Juni Tahun 2017. Sebagaimana dikemukakan oleh Arikunto (2002: 3) Penelitian eksperimen adalah suatu cara untuk mencari hubungan sebab akibat (hubungan kausal) antara dua faktor yang sengaja ditimbulkan oleh peneliti dengan mengeliminasi atau mengurangi atau menyisihkan faktorfaktor lain yang bias mengganggu. Penelitian yang akan dilakukan oleh peneliti adalah desain penelitian quasi eksperimental design. Penelitian quasi eksperimental design merupakan pengembangan dari desain penelitian true eksperimental design. Penelitian quasi eksperimental design merupakan penelitian yang menggunakan kelompok control, namun kelompok kontrol tersebut tidak berfungsi sepenuhnya untuk mengontrol variabel-variabel luar yang mempengaruhi pelaksanaan eksperimen. Eksperimen selalu dilakukan dengan maksud untuk melihat akibat dari suatu perlakuan sehingga diperoleh informasi mengenai efek variabel satu dengan variabel yang lain. Penelitian eksperimen dilakukan untuk meneliti pengaruh dari treatment yang diberikan, dalam hal ini hanya menggunakan satu kelas eksperimen. Dengan kata lain, suatu penelitian yang dilakukan dengan memberikan perlakuan pada individu yang diamati.

Menurut Sugiyono (2009: 110) menyebutkan terdapat beberapa bentuk desain eksperimen yang dapat digunakan dalam penelitian, yaitu: Pre eksperimental design, true eksperimental design, factorial design, dan quasi eksperimental design. Pada penelitian ini peneliti menggunakan pre eksperimental design. Penelitian eksperimental berhubungan erat dengan adanya pengaruh, yakni adanya variabel $\mathrm{X}$ yang diberikan dalam suatu kondisi atau keadaan khusus, diatur dan dikelola oleh peneliti sehingga dapat memberikan kesan atau akibat pada variabel Y. Desain eksperimen yang digunakan dalam penelitian ini adalah one-group pre test and post test design. Desain ini, subyek dikenakan 2 kali pengukuran. Pengukuran yang 
pertama dilakukan untuk mengukur kemampuan manajemen waktu sebelum siswa diberilakn kegiatan layanan penguasaan konten dengan teknik kontrak perilaku melalui pre test dan pengukuran yang kedua untuk mengukur kemampuan manajemen waktu sesudah sisiwa diberikan kegiatan layanan penguasaan konten dengan teknik kontrak perilaku melalui pos test. Desain ini dapat digambarkan sebagai berikut:

\section{$01 \quad \mathrm{X} \quad 02$}

Keterangan :

O1 : nilai pre test, untuk mengukur tingkat kemampuan manajemen waktu siswa sebelum diberi perlakuan layanan penguasaan konten dengan teknik kontrak perilaku.

X : treatment, pelaksanaan pada layanan penguasaan konten dengan teknik kontrak perilaku.

O2 : nilai post test, digunakan yang mengukur tingkat perkembangan kemempuan manajemen waktu siswa setelah diberi perlakuan layanan penguasaan konten dengan teknik kontrak perilaku.

Dengan demikian, pengukuran dilakukan sebanyak dua kali yaitu sebelum dan setelah pemberian perlakuan dengan menggunakan instrument yang sama yaitu angket kemampuan manajemen waktu.

Menurut Sugiyono (2008:55) "populasi adalah wilayah generalisasi yang terdiri atas obyek/subyek yang mempunyai kualitas dan karakteristik tertentu yang diterapkan oleh peneliti untuk dipelajari dan ditarik kesimpulannya". Mengenai populasi dalam penelitian ini perlu dikemukakan sebagai berikut : suatu penelitian akan memenuhi nilai-nilai ilmiah jika penelitian ini memerhatikan dan membatasi populasi yang dijadikan subyek penelitian, hal ini didasarkan penggeneralisasian hasil penelitian di dalam suatu populasi tertentu. Apabila subyek dalam populasi kurang dari 100 lebih baik diambil semua, sehingga penelitian merupakan penelitian populasi.

Berdasarkan definisi di atas, maka dapat diartikan bahwa populasi adalah keseluruhan individu atau objek penelitian yang diduga memiliki sifat dan karakteristik yang sama. Selanjutnya dalam penelitian ini yang dijadikan populasi adalah siswa kelas VIII SMP N 5 Tebing Tinggi dengan jumlah 224 siswa.

Sampel merupakan bagian dari populasi yang akan diteliti. Menurut Sugiyono (2008: 56) "Sampel adalah bagian dari jumlah dan karakteristik yang dimiliki oleh populasi tersebut." Dengan demikian sampel adalah sebagian dari jumlah populasi yang akan diteliti dengan melihat 
karakteristik yang ingin diteliti. Teknik sampling merupakan teknik pengambilan sampel. Sampel dalam penelitian ini diambil dengan teknik purposeive sampling. Hal itu disebabkan karena objek penelitian adalah siswa yang memiliki kemampuan manajemen waktu yang rendah yaitu siswa kelas VIII-2 sebanyak 28 siswa. Hal ini telah sesuai dengan yang disampaikan oleh (Sugiyono, 2008:85) bahwa "sampling purposive adalah teknik penentuan sampel dengan pertimbangan tertentu."

Alat pengumpul data yang digunakan dalam penelitian ini adalah kuesioner kemampuan manajemen waktu yang telah dikembangkan oleh peneliti berdasarkan teori. Alat ukur yang dikembangkan dalam penelitian ini adalah alat yang digunakan untuk memperoleh gambaran tingkat perkembangan kemampuan manajemen waktu kelas VIII SMP N 5 Tebing Tinggi.

Melakukan sebuah penelitian hendaknya menggunakan alat ukur yang baik. Alat ukur yang dipakai dalam penelitian ini diutamakan sebagai instrument penelitian. Instrument yang digunakan dalam penelitian ini disusun sendiri oleh peneliti berdasarkan pada teori-teori yang mendasari variabel penelitian.

Validitas merujuk kepada suatu ukuran yang menunjukkan tingkat kevalidan atau kesahihan suatu instrumen. Instrumen yang valid berarti alat ukur yang digunakan untuk mendapatkan data(mengukur) itu valid. Valid berarti instrumen tersebut dapat digunakan untuk mengukur apa yang seharusnya diukur (Sugiyono, 2008:121). Peneliti mengukur validitas dengan melakukan uji coba instrumen di lapangan. Jadi instrumen yang telah disusun diujicobakan di lapangan kemudian diukur validitasnya. Dalam penelitian ini, peneliti menggunakan validitas konstruk (construct validity) dengan melakukan uji coba instrumen. Cara pengukuran untuk mengetahui valid/tidaknya dilakukan dengan mengunakan rumus korelasi product moment oleh Pearson

\section{HASIL PENELITIAN DAN PEMBAHASAN}

Berdasarkan pada tujuan penelitian, maka hasil penelitian yang dapat dilaporkan yaitu tentang kemampuan manajemen waktu siswa kelas VIII-2 SMP Negeri 5 Tebing Tinggi sebelum diberi layanan penguasaan konten dengan teknik kontrak perilaku, gambaran kemampuan manajemen waktu siswa kelas VIII-2 SMP Negeri 5 Tebing Tinggi setelah diberi layanan penguasaan konten dengan teknik kontrak perilaku, dan perbedaan sebelum dan sesudah mengikuti layanan penguasaan konten dengan teknik kontrak perilaku. dapat diketahui bahwa dari 28 siswa tersebut secara umum mengalami perkembangan kemampuan 
manajemen waktu. Dari perhitungan persentase rata-rata kemampuan manajemen waktu sebelum mendapatkan perlakuan adalah $57,80 \%$ sehingga termasuk kategori sedang. Namun setelah mendapatkan perlakuan persentase rata-rata tersebut mengalami peningkatan sebesar $13,72 \%$ menjadi $71,52 \%$ sehingga termasuk dalam kategori tinggi. Untuk lebih jelasnya hasil analisis deskriptif persentase sebelum dan setelah diberi perlakuan dari tiap-tiap indikator kemampuan manajemen waktu dapat disajikan. Secara keseluruhan, layanan penguasaan konten dengan teknik kontrak perilaku dapat mengembangkan kemampuan

manajemen waktu siswa.

Perkembangan itu dapat dilihat sebelum diberi layanan dan setelah diberi layanan penguasaan konten dengan teknik kontrak perilaku, mengalami perubahan yang dapat dilihat pada saat siswa ada dalam situasi kegiatan berlangsung dan setelah diberi penilaian siswa mendapatkan pemahaman, perasaan senang dan tindakan yang akan dilakukan setelah mendapatkan perlakuan, sehingga siswa dapat menerapkan dalam kehidupan sehariharinya. Hal ini menunjukkan adanya kesesuaian dengan hasil analisis data yang secara statistik menunjukkan bahwa penguasaan konten dengan teknik kontrak perilaku dapat meningkatkan kemampuan manajemen waktu kelas VIII-2 SMP Negeri 5 Tebing Tinggi.

\section{Pembahasan}

Berdasarkan pada tujuan dan hasil penelitian, maka akan dibahas secara eksplisit tentang gambaran kemampuan manajemen waktu siswa kelas VIII-2 SMP Negeri 5 Tebing Tinggi sebelum diberi layanan penguasaan konten dengan teknik kontrak perilaku, gambaran kemampuan manajemen waktu siswa kelas VIII-2 SMP Negeri 5 Tebing Tinggi setelah diberi layanan penguasaan konten dengan teknik kontrak perilaku, dan perbedaan kemampuan manajemen waktu kelas VIII-2 SMP Negeri 5 Tebing Tinggi sebelum dan setelah mengikuti layanan penguasaan konten teknik kontrak perilaku.

Berdasarkan perhitungan analisis deskriptif, dapat diketahui bahwa sebelum diberikan layanan penguasaan konten teknik kontrak perilaku gambaran kemampuan manajemen waktu dari 28 siswa, secara umum diperoleh persentase $57,80 \%$ dan menunjukkan kategori sedang dimana terdapat 8 siswa atau $28,57 \%$ memiliki kategori rendah. Siswa yang memiliki kategori sedang yaitu 20 siswa atau 71,43\%, sedangkan siswa yang memiliki kemampuan manajemen waktu dengan kategori tinggi dan sangat tinggi tidak ada. Hal ini menunjukkan bahwa sebagian besar siswa belum memahami karakteristik 
manajemen waktu yang baik yaitu mampu menyusun tujuan, mampu menyusun prioritas, mampu membuat jadwal, mampu meminimalisir gangguan, mampu mendelegasikan tugas. Berdasarkan uraian di atas, menunjukkan bahwa terjadi perkembangan kemampuan manajemen waktu pada semua indikator. Meskipun begitu, hendaknya perlu dikembangkan lagi. Tindak lanjut yang perlu dilaksanakan yaitu guru pembimbing hendaknya terus mendampingi siswa menekankan pentingnya menyusun tujuan hidup, menyusun prioritas, membuat jadwal, meminimalisir gangguan dan mendelegasikan tugas. Hal tersebut bisa dilakukan melalui layanan klasikal ataupun format kelompok. Selain itu, guru pembimbing juga perlu memperhatikan faktor eksternal yang mempengaruhi manajemen waktu siswa misalnya lingkungan keluarga dan pergaulan teman sebaya.

\section{SIMPULAN}

Berdasarkan hasil peneltian dan pembahasan, maka dapat disimpulkan bahwa kemampuan manajemen waktu dapat dikembangkan melalui layanan penguasaan konten dengan teknik kontrak perilaku pada siswa kelas VIII-2 SMP N 5 Tebing Tinggi. Dari simpulan utama tersebut dapat dijabarkan simpulan sebagai berikut :

Manajemen waktu siswa kelas VIII-2 SMP Negeri 5 Tebing Tinggi sebelum mengikuti layanan penguasaan konten dengan teknik kontrak perilaku menunjukkan kategori sedang.

Manajemen waktu siswa kelas VIII-2 SMP Negeri 5 Tebing Tinggi setelah mengkuti layanan penguasaan konten dengan teknik kontrak perilaku menunjukkan kategori tinggi.

Ada perbedaan yang signifikan antara kemampuan manajemen waktu sebelum dan setelah diberikan perlakuan, dimana terjadi perkembangan kemampuan manajemen waktu setelah diberikan perlakuan layanan penguasaan konten dengan teknik kontrak perilaku. Hal ini didukung pula oleh hasil pengamatan terhadap subyek selama diberikan perlakuan.

Berdasarkan hasil penelitian ini dibuktikan adanya perkembangan kemampuan manajemen waktu siswa setelah mendapatkan layanan penguasaan konten dengan teknik kontrak perilaku, maka ada beberapa saran yang dapat dipergunakan sebagai bahan pertimbangan yaitu: Guru pembimbing SMP Negeri 5 Tebing Tinggi, agar lebih mengintensifkan layanan penguasaan konten dengan teknik kontrak perilaku kepada siswa sebagai strategi alternative untuk membantu siswa mengembangkan kemampuan manajemen waktu. Untuk yang tertarik agar melakukan penelitian dengan setting lain. Misalnya, di SMP dengan menggunakan layanan bimbingan konseling selain layanan penguasaan konten dalam membingkai teknik 
S. Rosnetty Saragih : Mengembangkan Kemampuan ...

kontrak perilaku, sehingga akan diperoleh masukan tambahan mengenai pengaruh karakteristik siswa terhadap efektifitas pemberian layanan bimbingan konseling dengan teknik kontrak perilaku.

\section{DAFTAR RUJUKAN}

Goliszek, Andrew. 2005. 60 Second Manajeman stress. Jakarta: Bhuana Ilmu Populer.

Hantoro, Eri. 2010. Upaya Meningkatkan Motivasi Belajar Siswa Melalui Layanan Penguasaan Konten Pada Siswa Kelas XI IA Di SMA PGRI 1 Sragen tahun ajaran 2009/2010. Penelitian.

Nursalim, Mochamad. 2007. Pemahaman Individu Melalui Teknik Non Tes. Surabaya: Unesa University Press.

Prayitno. 2004. Layanan Bimbingan dan Konseling. Padang: Universitas Negeri Padang.

Reza, J J. 2010. Manage Your Time for Success Cerdas Mengelola Waktu untuk Mencapai Sukses. Yogyakarta : ANDI.

Sugiyono. 2008. Statistika untuk Penelitian. Bandung: Alfabeta.

Trimo. 2008. Bimbingan dan Konseling Karier di Sekolah Dasar. Artikel.

Wingkel W.S \& M.M Sri Hastuti. 2005. Bimbingan dan Konseling di Institusi Pendidikan. Yogyakarta : Media Abadi. 